\title{
Clopidogrel-induced pneumonia
}

\author{
Yoshitaka Tomoda, ${ }^{1}$ Takashi Miyajima, ${ }^{2}$ Chinami Nagasawa, ${ }^{2}$ Yukikazu Awaya ${ }^{2}$
}

${ }^{1}$ General Medicine, Itabashi Chuo Medical Center, Tokyo, Japan

${ }^{2}$ Respiratory Medicine, Itabashi Chuo Medical Center, Tokyo, Japan

Correspondence to Dr Yoshitaka Tomoda: yoshisoph@gmail.com

Accepted 3 June 2021

\section{DESCRIPTION}

A 75 -year-old man was admitted to our hospital with progressive dyspnoea on effort and cough. Three months before presentation, he had undergone percutaneous coronary intervention for unstable angina. At that time, he began taking aspirin (100 mg daily) and clopidogrel (75 mg daily). He had no history of exposure to pets or humidifiers. Repeated PCR for SARS-CoV-2 was negative. Physical examination revealed neither lymphadenopathy nor skin rash. Laboratory tests including blood cell count, antinuclear antibody, antineutrophil cytoplasmic antibodies and ACE were normal. Initial chest X-ray and CT revealed diffuse ground-glass opacifications and reticular shadows in the bilateral lungs (figure 1). He underwent diagnostic bronchoscopy. Bronchoalveolar lavage fluid (BALF) was sterile and contained 517 white cells $/ \mathrm{mm}^{3}$ (48\% lymphocytes, 37\% macrophages, 3\% neutrophils and $12 \%$ eosinophils). Cultures of sputum and BALF were negative for bacterial and mycobacterial pathogens. Histopathological examination of the transbronchial lung biopsy specimen revealed subacute interstitial pneumonia including organising pneumonia. Specific inflammatory disorders were carefully excluded, and he was diagnosed with clopidogrel-induced pneumonia. Discontinuation of clopidogrel resulted in partial improvement in the patient's symptoms and radiographic abnormalities, and both resolved after administration of $0.5 \mathrm{mg} / \mathrm{kg}$ prednisolone (figure 2); the prednisolone was gradually tapered over a 2 -month period.

Clopidogrel, a thienopyridine drug that inhibits platelet aggregation, is widely used to reduce the risk of fatal thrombosis with newly implanted coronary stents. Clopidogrel-induced lung injury has been reported, including bleeding events such as alveolar haemorrhage as well as

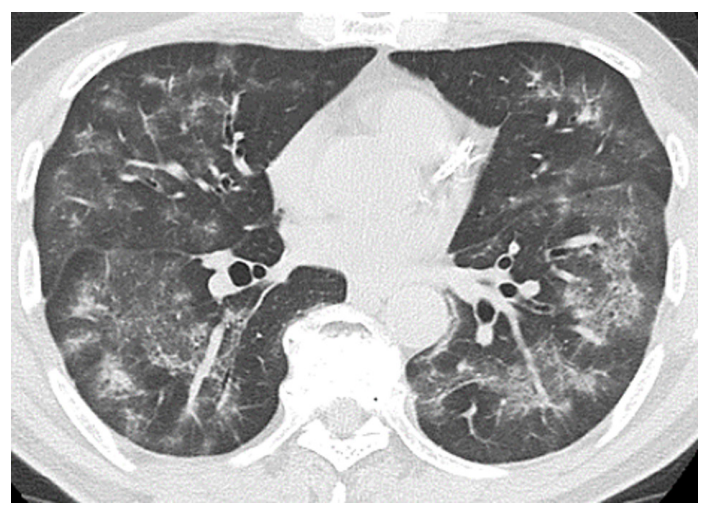

Figure 1 Chest CT revealed diffuse ground-glass opacifications.

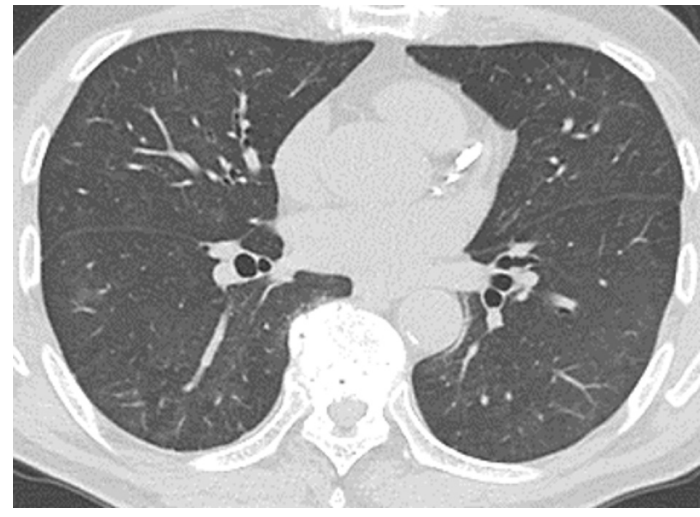

Figure 2 Follow-up chest CT 6 months later revealed resolution of radiographic abnormalities.

interstitial lung diseases such as eosinophilic pneumonia or organising pneumonia. ${ }^{12}$ Cases of drug-induced pneumonia have also been reported with ticlopidine, a thienopyridine drug-like clopidogrel. ${ }^{3}$ Similar to ticlopidine, clopidogrel-induced pneumonia has been reported to occur several months after administration. Various differential diagnoses of radiological findings of our case, diffuse ground-glass opacifications with consolidative abnormalities, are needed that observed in hypersensitivity pneumonitis, eosinophilic pneumonia, interstitial pneumonia with connective tissue disease or COVID-19. ${ }^{4}$ No specific tests established drug-induced pneumonia, and the diagnosis can be made on the basis of the combination of medical history, laboratory testing, imaging and bronchoscopy. The optimal treatment of drug-induced pneumonia is not established, but discontinuation of the suspect drug and systemic glucocorticoid therapy are the main treatment. There is no evidence of the initial dose and duration of glucocorticoid therapy. Especially during the COVID-19 pandemic, drug-induced pneumonia can be confused with COVID-19 due to similarities in radiological findings. In the case of unexplained chest imaging abnormalities, clinicians should be aware of the risk

\section{Learning points}

A detailed medical history is necessary for the diagnosis of drug-induced pneumonia.

- Clopidogrel can cause drug-induced pneumonia.

- During COVID-19 pandemic, drug-induced pneumonia is one of the differential diagnoses of ground-glass opacifications on chest CT. 
of drug-induced pneumonia and basic medical history such as current medication.

\section{Twitter Yoshitaka Tomoda @Y-Tomo}

Acknowledgements The authors would like to thank Yuh Fukuda (Division of Diagnostic Pathology, Itabashi Chuo Medical Center, Tokyo, Japan) for the histological evaluation of lung biopsy.

Contributors YT wrote the paper. TM and CN acquired data. YA critically revised the manuscript. All authors have read and approved the final manuscript.

Funding The authors have not declared a specific grant for this research from any funding agency in the public, commercial or not-for-profit sectors.

Competing interests None declared.
Patient consent for publication Obtained.

Provenance and peer review Not commissioned; externally peer reviewed.

\section{REFERENCES}

1 Gill DS, Ng K, Ng K-S. Massive pulmonary haemorrhage complicating the treatment of acute coronary syndrome. Heart 2004;90:e15.

2 Inagaki Y, Tachibana K, Inoue Y, et al. Severe clopidogrel-induced dress with eosinophilic pneumonia associated with Epstein-Barr virus reactivation. Respirol Case Rep 2020;8:e00541.

3 Alonso-Martinez JL, Elejalde-Guerra JI, Larrínaga-Liñero D. Bronchiolitis obliteransorganizing pneumonia caused by ticlopidine. Ann Intern Med 1998;129:71-2.

4 Bao C, Liu X, Zhang H, et al. Coronavirus disease 2019 (COVID-19) CT findings: a systematic review and meta-analysis. J Am Coll Radiol 2020;17:701-9.

Copyright 2021 BMJ Publishing Group. All rights reserved. For permission to reuse any of this content visit https://www.bmj.com/company/products-services/rights-and-licensing/permissions/

BMJ Case Report Fellows may re-use this article for personal use and teaching without any further permission.

Become a Fellow of BMJ Case Reports today and you can:

- Submit as many cases as you like

- Enjoy fast sympathetic peer review and rapid publication of accepted articles

- Access all the published articles

- Re-use any of the published material for personal use and teaching without further permission

Customer Service

If you have any further queries about your subscription, please contact our customer services team on +44 (0) 2071111105 or via email at support@bmj.com.

Visit casereports.bmj.com for more articles like this and to become a Fellow 